UII norden

Kontroll av klassifisering og merking av kjemiske stoffer og blandinger etter det nye CLP-regelverket

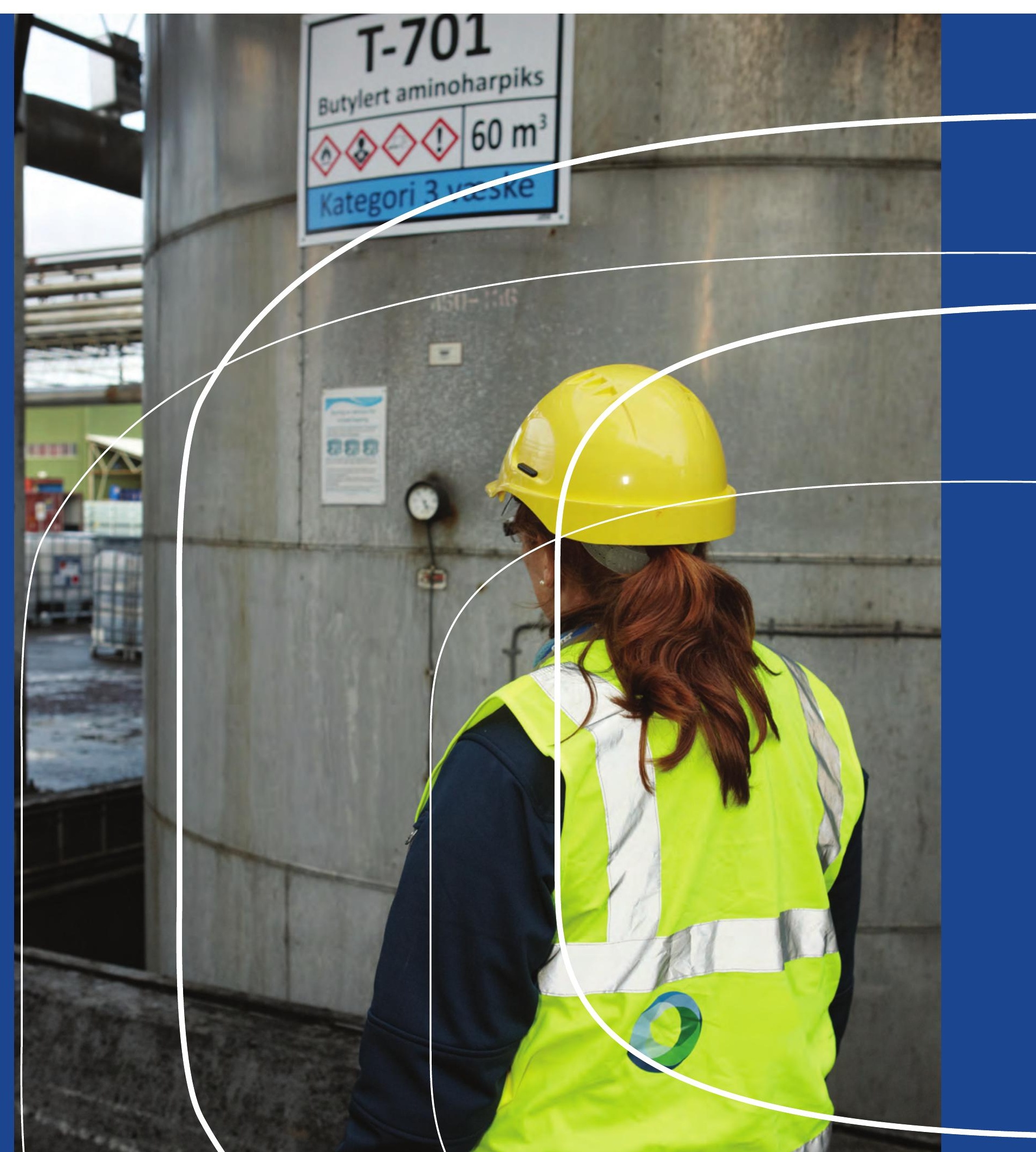



4 norden 



\section{Kontroll av klassifisering og merking av kjemiske stoffer og blandinger etter det nye CLP-regelverket}

Nordisk tilsynsprosjekt 2012-2013

Dorrit Skals, Britt Joanna Harder, Susanna Norrthon Risberg, Jörgen Rosberg, Anna Forsbacka, Sari Tuhkunen, Kari Løkken og Gro Hagen 
Kontroll av klassifisering og merking av kjemiske stoffer og blandinger etter det nye CLP-regelverket Nordisk tilsynsprosjekt 2012-2013

Dorrit Skals, Britt Joanna Harder, Susanna Norrthon Risberg, Jörgen Rosberg, Anna Forsbacka, Sari Tuhkunen, Kari Løkken og Gro Hagen

ISBN 978-92-893-2627-8

http://dx.doi.org/10.6027/TN2013-565

TemaNord 2013:565

(c) Nordisk ministerråd 2013

Layout: Hanne Lebech

Omslagsfoto: John Petter Reinertsen

Denne rapporten er gitt ut med finansiell støtte fra Nordisk ministerråd. Innholdet i rapporten avspeiler imidlertid ikke nødvendigvis Nordisk ministerråds synspunkter, holdninger eller anbefalinger.

\section{www.norden.org/no/publikasjoner}

\section{Det nordiske samarbeidet}

Det nordiske samarbeidet er en av verdens mest omfattende regionale samarbeidsformer. Samarbeidet omfatter Danmark, Finland, Island, Norge og Sverige samt Færøyene, Grønland og Åland.

Det nordiske samarbeidet er både politisk, økonomisk og kulturelt forankret, og er en viktig medspiller i det europeiske og internasjonale samarbeid. Det nordiske fellesskapet arbeider for et sterkt Norden i et sterkt Europa.

Det nordiske samarbeidet ønsker å styrke nordiske og regionale interesser og verdier i en global omverden. Felles verdier landene imellom bidrar til å styrke Nordens posisjon som en av verdens mest innovative og konkurransekraftige regioner.

\section{Nordisk ministerråd}

Ved Stranden 18

DK-1061 København K

Telefon (+45) 33960200

\section{www.norden.org}




\section{Innholdsfortegnelse}

Forord

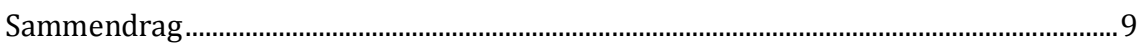

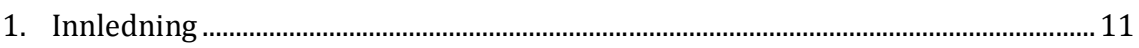

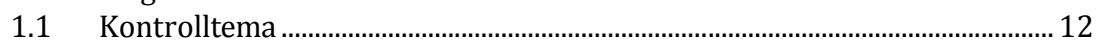

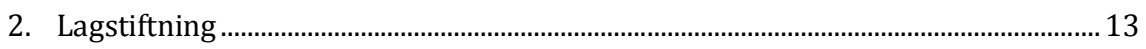

2.1 Direktiv och förordningar ............................................................................... 13

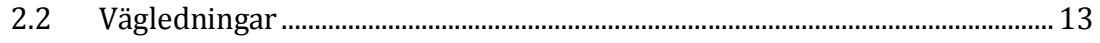

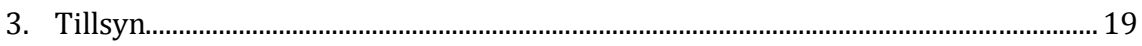

4. Resultater og konklusjoner .............................................................................................. 21

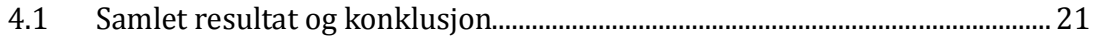

5. Summary and conclusion....................................................................................... 33

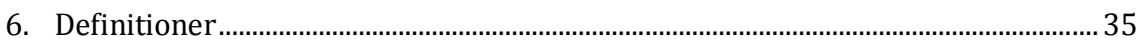

7. Bilag 1: Sjekkliste ................................................................................................................

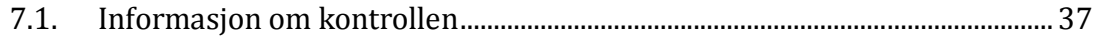

7.2. Kontroll av notifisering (art. 39 \& 40) ………………………………………..... 37

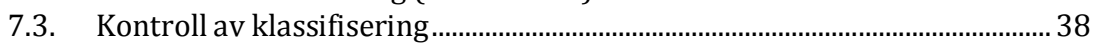

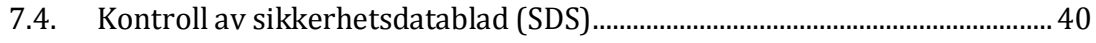

7.5. Kontroll av etikett/merking ............................................................................. 41

7.6. Kontroll av barnesikret lukning og følbar advarselsmerking (art.35)

dersom noen av de kontrollerte stoffene/stoffblandingene leveres til

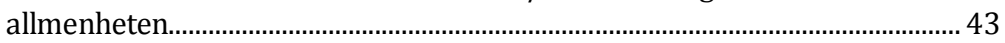

7.7. Kontroll av Netthandel (art 48) ............................................................................. 43 



\section{Forord}

Kjemikaliemyndighetene i de nordiske landene har i mange år samarbeidet om felles tilsynsprosjekter for å sikre større gjennomslagskraft og skape større likhet i tolkningen av felles EU-regler på kjemikalieområdet. Dette blir viktigere og viktigere med tanke på de mange forordninger som er kommet de senere årene (CLP, REACH) og som er underveis (Biocidforordningen).

Tidligere ble reglene utformet som direktiver, som skulle implementeres i nasjonale forskrifter, men nå utarbeides det mest forordninger som er direkte rettsgjeldende i alle EU/EØS landene. Det er derfor svært viktig at tilsynsmyndighetene i de enkelte land tolker regelverket ensartet.

Tilsynsprosjektene er forankret i Tilsynsgruppen, som er en undergruppe av Nordisk kjemikaliegruppe i Nordisk Ministerråd. Tilsynsgruppen har som formål å utveksle erfaringer mellom landene vedrørende kjemikaliekontroll og gjennomføre felles tilsynsprosjekter. Gruppen møtes en gang per år til et felles møte

Dette tilsynsprosjektet ble startet opp i 2012 og avsluttet i 2013, og har fokus på klassifisering og merking etter det nye kjemikalie-regelverket CLP (Classification, labelling and packaging of substances and mixtures).

Klima- og forurensningsdirektoratet (Klif) i Norge har vært prosjektleder ved Cathrine Skjærgård, Gro Hagen og Kari Løkken. Deltakere fra de andre nordiske landene har vært: Dorrit Skals og Britt Joanna Harder fra Miljøstyrelsens Kemikalieinspektion i Danmark, Susanna Norrthon Risberg og Jörgen Rosberg fra Kemikalieinspektionen i Sverige og Anna Forsbacka og Sari Tuhkunen fra Tukes i Finland. 



\section{Sammendrag}

Formålet til prosjektet har vært å kontrollere om stoffer er klassifisert og merket korrekt etter de nye klassifiserings- og merkingsreglene CLP (Classification, Labelling and Packaging).

CLP-forordning trådte i kraft i 2010. Alle stoffer som er plassert på markedet skal være klassifisert og merket i henhold til CLP fra 1 desember 2012. Blandinger skal være klassifisert og merket i henhold til CLP fra 2015, imidlertid kan CLP brukes frivillig for blandinger før det.

I tillegg har det også blitt kontrollert notifisering av stoffer (CLP art 40), klassifisering og merking av stoffblandinger og nye krav til sikkerhetsdatablader (SDS) i forordning 453/2010 (revideret vedlegg II til REACH). ${ }^{1}$

Prosjektet ble gjennomført fra mai 2012 til juni 2013. Deltagere har vært Sverige, Danmark, Finland og Norge og prosjektgruppen har bestått av to representanter fra hvert land. Det har vært gjennomført to prosjektmøter, ett oppstartsmøte i mai 2012 og en to-dagers workshop i april 2013. All annen kommunikasjon har gått via e-mail og en felles webbasert prosjektmappe.

Det er kontrollert totalt 90 stoffer i de fire landene og det var kun ett stoff som manglet CLP klassifisering. Det er et meget godt resultat.

De fleste virksomhetene der vi kontrollerte stoffblandinger, har begynt å klassifisere og merke blandingene sine etter CLP. Ikke alle var i mål med å legge om til CLP for hele produktsortimentet. Dette skyldes hovedsaklig at mange leverandører har et stort produktspekter og distribusjon i mange land og at det tar tid å utarbeide sikkerhetsdatablader og merkeetiketter på mange språk.

Stoffer som har en harmonisert klassifisering, det vil si en klassifisering som EU/EØS-landene er enige om, skal i følge CLP, benytte den klassifiseringen. Resultatene viser at virksomhetene har benyttet korrekt harmonisert klassifisering for alle de kontrollerte stoffene.

\footnotetext{
${ }^{1}$ Europa-Parlamentets og Rådets forordning (EF) nr. 1907/2006 av 18. desember 2006 om registrering vurdering og godkjenning og begrensninger for kjemikalier (REACH).
} 
Tilsvarende har virksomhetene benyttet korrekt harmonisert klassifisering for $80 \%$ av stoffene i de kontrollerte stoffblandingene.

Når det gjelder notifisering/melding om klassifisering og merking av stoffer til ECHA (det europeiske kjemikaliebyrået), viser resultatene at de fleste kontrollerte virksomhetene velger å handle med leverandører i EU for å slippe registrering i henhold til REACH og notifisering i henhold til CLP.

For totalt 134 kontrollerte sikkerhetsdatablader (SDS), var det kun 3 som ikke var i henhold til revidert vedlegg II i REACH (forordning 453/2010). Disse 3 ble imidlertid funnet i Norge, der revidert vedlegg II ikke var implementert på kontrolltidspunktet.

Sikkerhetsdatablader ble ikke kontrollert i Danmark, da det er en annen tilsynsmyndighet enn Miljøstyrelsen som har hovedansvaret for kontroll av SDS i Danmark.

Det er kontrollert 138 etiketter totalt. Resultatene viser at det ble funnet en del feil ved CLP-klassifiseringen av stoffblandinger. Det kan tyde på at det er utfordrende for virksomhetene å klassifisere blandinger etter det nye regelverket.

Resultatene fra prosjektet viser at klassifisering og merking av stoffer etter CLP er gjennomført hos alle de kontrollerte virksomhetene. I alle de fire nordiske landene er klassifisering og merking av stoffblandinger etter CLP også godt i gang. Resultatene viser imidlertid en del feil ved klassifisering og merking av stoffblandinger, og det kan tyde på at det nye regelverket er noe mer utfordrende for stoffblandinger enn for stoffer.

Alt i alt viser resultatene fra inspeksjonsprosjektet at virksomhetene har lykkes bra i overgangen til CLP og det nye formatet for sikkerhetsdatabladene, da ingen alvorlige mangler ble avdekket. 


\section{Innledning}

CLP-forordningen er det nye europæiske klassificeringssystem for kemiske stoffer og blandinger. CLP står for Classification, Labelling and Packaging, og er baseret på det globale GHS system (Globally Harmonised System of classification and labelling) under FN.

CLP-forordningen trådte i kraft i 2010. Forordningen erstatter på sigt det gamle stofdirektiv (67/548/EØF) og præparatdirektiv (1999/45/EF).

CLP-forordningen omfatter stoffer og blandinger som markedsføres i EU/EøS. Markedsføring defineres som "Levere eller stille til rådighed for tredje part". Import af stoffer og blandinger fra et ikke-EU land og ind i EU/EøS betragtes i denne sammenhæng også som markedsføring.

Siden 1. december 2010 skal alle kemiske stoffer klassificeres i henhold til CLP, mens blandinger først skal være klassificeret efter CLP fra 1. juni 2015. Af hensyn til den senere frist for omklassificering af blandinger, skal stoffer indtil 1. juni 2015 være forsynet med dobbelt klassificering i sikkerhedsdatabladet, dvs. både i henhold til klassificeringsreglerne i Præparatdirektivet (DSD) og CLP-forordningen.

Tilsynsgruppen under NKG har i 2010 og 2011 arrangeret oplæringsaktiviteter indenfor de nye regler for klassificering og mærkning af kemikalier, CLP.

For at følge op på disse oplæringsaktiviteter blev det på Nordisk møde i maj 2011 besluttet at gennemføre et fælles tilsynsprojekt med CLP som tema i 2012.

Fokusområderne i projektet var kontrol af rene stoffer i henhold til notificering, klassifisering og mærkning. Desuden indgik kontrol af, om SDS lever op til de nye krav i forordning 453/2010 (revideret tillæg til REACH) ${ }^{2}$ også her.

Det blev besluttet at begrænse projektet til kontrol af minst 6-8 virksomheder pr. land for at give et indblik i, hvordan virksomhederne håndterer disse nye forpligtelser. På baggrund af resultaterne ville de

2 Europa-Parlamentets og Rådets forordning (EF) nr. 1907/2006 af 18. december 2006 om registrering, vurdering og godkendelses samt begrænsninger for kemikalier (REACH). 
enkelte lande sidenhen kunne beslutte, om der var områder, der skulle fokuseres ekstra på mht. vejledning, tilsyn mv.

Som udgangspunkt blev det aftalt, at landene ville koncentrere sig om tilsyn hos store koncerner/kæder, som var repræsenteret i samtlige nordiske lande. Baggrunden for dette var at arbejde for større ensartethed i forståelsen omkring tolkningen af reglerne de nordiske myndigheder imellem.

Landene gik dog bort fra dette igen, da det viste sig, at de fleste af disse koncerner har hovedkontor i et enkelt nordisk land, og herfra styrer registrering, notificering, klassificering, mærkning og udarbejdelse af sikkerhedsdatablade mv. Afdelingerne i de andre nordiske lande er derfor at betragte som downstream users/distributors, og derfor ikke har disse forpligtelser. Det vil derfor ikke give mening at føre tilsyn hos dem.

\subsection{Kontrolltema}

Følgende temaer indgik i kontrollen:

- Notificering til C\&L inventory/ECHA (CLP art 40).

- Kontroll av klassifisering og merking på etikett.

- Kontroll av klassifisering og merking i SDS.

- Samsvar SDS, etikett og C\&L inventory.

- Kontroll av emballasje - barnesikret lukning/folbar advarselmerking.

For at udnytte ressourcerne optimalt valgte nogle lande også at kontrollere f.eks. om virksomhederne havde registreret i henhold til kraven $i$ REACH-forordningen. Der henvises til kapitel 4 for nærmere beskrivelse af udførelsen af de enkelte landes kontroller. 


\section{Lagstiftning}

\subsection{Direktiv och förordningar}

Följande EU-direktiv och förordningar var relevanta för projektet:

- CLP (EG) nr 1272/2008.

- REACH (EG) nr 1907/2006, bilaga II ändrad genom förordning (EG) nr 453/2010.

- Direktiv 67/548/EEG (ämnesdirektivet).

- Direktiv 1999/45/EEG (preparatdirektivet).

\subsection{Vägledningar}

Den europeiska kemikaliemyndigheten ECHA har tagit fram flera vägledningsdokument som ger vägledning för både företag och tillsynsmyndigheter kring reglerna i CLP och REACH. Vägledningsdokumenten finns tillgängliga på ECHA's webbplats http://ECHA.europa.eu. Följande vägledningar var relevanta för projektet:

- Inledande vägledning om CLP-förordningen.

- Vägledning om märkning och förpackning enligt förordning (EG) $\mathrm{nr}$ $1272 / 2008$.

- Vägledning om tillåmpning av CLP-kriterierna.

- Praktisk vägledning 7: Hur ett ämne anmäls till klassificerings- och märkningsregistret.

- Vägledning om sammanställning av säkerhetsdatablad.

\subsubsection{CLP-förordningen}

CLP-förordningen (EG) nr 1272/2008 innehåller regler om klassificering, märkning och förpackning av kemiska ämnen och blandningar. Den ändrar och upphäver direktiven 67/548/EEG och 1999/45/EG samt ändrar förordning (EG) $\mathrm{nr}$ 1907/2006 (Reach). Lagstiftningen som trädde i kraft den 20 januari 2009 gäller i hela EU och inför ett nytt system för klassificering och märkning av kemikalier, som grundas på FN:s 
globalt harmoniserade system (GHS). Eftersom CLP är en EU-förordning gäller den direkt i hela EU utan att först införas i nationella regler. För att företagen ska kunna anpassa sig till de nya reglerna införs CLPförordningen stegvis. Under en övergångsperiod fram till 2015 gäller CLP och direktiven därför parallellt.

Alla ämnen som släpps ut på marknaden ska klassificeras och märkas enligt CLP från den 1 december 2010. Blandningar ska klassificeras och märkas enligt CLP från och med 1 juni 2015, men CLP får tillämpas frivilligt för blandningar innan dess.

\section{Övergångsregler:}

Ämnen: Företagen måste fram till och med den 1 juni 2015 fortsätta att klassificera sina ämnen enligt ämnesdirektivet. Det är dessutom obligatoriskt att klassificera ämnena enligt CLP.

Det betyder att det blir dubbel klassificering, dvs. att både klassificering enligt äldre regler och enligt CLP måste finnas med i säkerhetsdatabladet fram till den 1 juni 2015. Märkningen ska dock aldrig vara dubbel, utan ämnen ska märkas och förpackas enligt CLP.

Blandningar: Företagen kan fortsätta att klassificera blandningar enligt preparatdirektivet fram till och med den 1 juni 2015. Den 1 juni 2015 upphör direktivet att gälla. Då ska blandningarna enbart klassificeras enligt CLP.

Blandningar som klassificerats och märkts enligt äldre regler och som redan släppts ut på marknaden före den 1 juni 2015 behöver dock inte märkas om och omförpackas förrän den 1 juni 2017.

\begin{tabular}{|c|c|c|c|}
\hline Ämnen & \multicolumn{2}{|c|}{ Gäller från 1.12.2010-1.6.2015 } & Efter 1.6.2015 \\
\hline Klassificering & \multicolumn{2}{|c|}{ DSD och CLP } & CLP \\
\hline Märkning & \multicolumn{2}{|l|}{ CLP } & CLP \\
\hline \multirow[t]{2}{*}{ Blandningar } & \multicolumn{2}{|c|}{ Gäller från 1.12.2010-1.6.2015 } & Efter 1.6.2015 \\
\hline & Antingen & Eller & \\
\hline Klassificering & DPD & DPD och CLP & CLP \\
\hline Märkning & DPD & CLP & CLP \\
\hline
\end{tabular}

Kemiska ämnen och blandningar ska klassificeras, märkas och förpackas enligt gällande regler innan de släpps ut på marknaden. Reglerna omfattar både kemikalier som säljs för privat konsumtion såväl som kemikalier för yrkesmässig användning. Reglerna finns för att säkerställa att användaren, och andra, får information om vilka kemiska produkter som 
är farliga, på vilket sätt de är farliga samt hur de ska kunna användas på ett säkert sätt.

Tillverkare, importörer och nedströmsanvändare av ämnen och blandningar är skyldiga att klassificera och märka sina produkter innan de släpps ut på marknaden. Detta gäller oavsett mängd.

Tillverkare, importörer och nedströmsanvändare måste använda harmoniserad klassificering för ämnen upptagna i bilaga VI till CLPförordningen för de faror de där klassificerats för. För andra faror och för de ämnen som saknar en harmoniserad klassificering ska företagen själva klassificera ämnena genom att använda kriterierna i avdelning II till CLP, så kallad egenklassificering.

Blandningar måste alltid egenklassificeras. Det betyder att en utvärdering måste ske om huruvida de uppfyller klassificeringskriterierna för hälsa, miljö eller fysikaliska egenskaper. För denna utvärdering måste hänsyn tas till alla tillgängliga harmoniserade klassificeringar av de ämnen som ingår i blandningen.

I projektet har märkning av kemiska produkter enligt avsnitt III i CLP förordningen kontrollerats. De parallella systemen för klassificering och märkning är i grunden lika men viktiga förändringar har införts i och med CLP, t.ex.:

- Nya och ändrade kriterier för klassificering. Detta gäller främst fysikaliska faror men även kriterier för hälsa och miljö (t.ex. akut toxicitet och frätande/irriterande egenskaper).

- En viktig skillnad är att märkningen enligt CLP har symboler mot vit bakgrund med röd ram (faropiktogram), istället för de "gamla" orangefärgade farosymbolerna.

- Farobeteckningar försvinner, istället används signalorden "Fara" och "Varning" (svensk), "Fare" og "Advarsel" (norsk, dansk),"Vaara" och "Varoitus" (finsk).

- Systemet med faro- och skyddsangivelser är likt men inte identiskt med risk- och skyddsfraser enligt direktiven.

- Förteckningen över ämnen med harmoniserad klassificering och märkning finns nu som bilaga VI till CLP. Bilagan innehåller harmoniserad klassificering enligt bägge sytemen (tabell 3.1 enligt CLP och tabell 3.2 enligt DSD). 


\section{Barnskyddande förslutning och kännbar varningsmärkning}

För att minska risken att barn eller synskadade skadas av kemikalier ska farliga kemiska produkter i vissa fall uppfylla särskilda förpackningskrav. Vissa kemiska produkter som säljs till allmänheten ska därför vara försedda med barnskyddande förslutning och kännbar varningsmärkning. Reglerna gäller oavsett förpackningens storlek. I reglerna finns hänvisningar till standarder som den barnskyddande förslutningen respektive kännbara varningsmärkningen ska uppfylla. Reglerna om barnskyddande förslutning och kännbar varningsmärkning återfinns i artikel 35 i CLP-förordningen.

\section{Klassificering- och märkningsregistret (Classification and Labelling Inventory)}

I och med CLP införs en ny skyldighet för tillverkare och importörer att anmäla sina ämnen till ECHA's klassificering- och märkningsregister. Ämnen ska anmälas inom en månad från det att de släppts ut på marknaden.

Tillverkare och importörer, eller grupper av tillverkare eller importörer, ska anmäla ett ämne om det släpps ut på marknaden och

- klassificeras som farligt enligt CLP, eller

- ska registreras enligt REACH (även om det inte klassificerats som farligt), eller

- ingår i en blandning i en halt som bidrar till att blandningen klassificeras som farlig enligt CLP (gäller endast vid import till EU/EES).

Anmälan ska göras oavsett i vilken mängd ämnena tillverkas eller importeras och oavsett om importen görs för eget bruk eller för vidare överlåtelse inom EU. Informationen som lämnats in i anmälningarna samlas i en databas som upprätthålls av ECHA och den är offentlig för alla att söka i. Det går inte att se vilken klassificering ett visst företag lämnat men det går att söka på ämnen och hitta vilka klassificeringar som anmälts och av hur många. Regler om anmälan till registret finns i CLP artikel 39-42.

\subsubsection{Säkerhetsdatablad}

Regler om säkerhetsdatablad (SDB) finns i REACH förordningen artikel 31 och bilaga 2 till REACH. Enligt ändringsförordning (EG) nr 453/2010, som trädde i kraft den 1 dec 2010, behöver innehållet i SDB uppdateras. Ändringarna innebär nytt innehåll i SDB för både ämnen och blandningar. Orsaken till ändringen är att SDB anpassas till CLP och till det globala 
systemet för klassificering och märkning av kemikalier, GHS. Ändringarna genomförs i två steg och därför innehåller den nya ändringsförordningen två bilagor. Bilaga I ska tillämpas mellan den 1 dec 2010 och den 1 juni 2015. Den 1 juni 2015 börjar bilaga II i ändringsförordningen att gälla fullt ut.

Under en övergångsperiod som gällde fram till 1 dec 2012 så fanns det en möjlighet för företagen att använda det "gamla" formatet för SDB. Efter den 1 dec 2012 ska alla SDB följa det nya formatet enligt ändringsförordningen.

Några viktiga förändringar för SDB som införs i och med det nya formatet är:

- Avsnitt 2 ska förutom klassificering även innehålla information om märkning. Märkning angavs tidigare i avsnitt 15.

- Mellan den 1 dec 2010 och 1 juni 2015 ska ämnens klassificering redovisas enligt DSD och CLP (dubbel klassificering). Det samma gäller för blandningar som frivilligt har klassificerats enligt CLP före den 1 juni 2015. Dubbel klassificering behövs för att företagen ska kunna klassificera blandningar enligt det äldreklassificeringssystemet fram till 2015.

- För ämnen ska dubbel klassificering anges under avsnitt 2 .

- För blandningar ska dubbel klassificering för ingående ämnen anges under avsnitt 3.

- Om CLP frivilligt tillämpas fullt ut för en blandning före 2015 ska även dubbel klassificering för blandningen anges under avsnitt 2 . 



\section{Tillsyn}

Projektet startade med ett projektmöte i slutet av maj 2012 för en diskussion om inriktning, omfattning, tidplan och fördelning av arbetsuppgifter inom projektet. Där beslutades att ta fram en gemensam checklista med vägledning och rapporteringsverktyg. Allt material som tagits fram inom projektet har lagts upp på en projektplats (Klif) som alla deltagare haft tillgång till under projektets gång. Det har upplevts som mycket positivt att ha allt material samlat och uppdaterat på samma plats. Till exempel har vi undvikit en del oklarheter om vilket dokument som är senaste version genom att använda projektplatsen.

Tidigare gemensamma nordiska tillsynsprojekt har tenderat att dra ut på tiden och dessutom har den aktiva inspektionsfasen varierat kraftigt mellan länderna. Därför har det i det här i projektet funnits ett uttalat mål att koncentrera ländernas aktiva tillsynsfas till samma period och att kunna slutföra projektet inom ett år.

Alla länder tog på sig att genomföra minst 6-8 inspektioner. Kontrollerna genomfördes under perioden 1 december 2012 och 15 februari 2013 i alla deltagande länder. Med få undantag genomfördes kontrollerna på plats hos företagen.

Det beslutades att Sverige skulle genomföra några pilotinspektioner för att testa den framtagna checklistan innan den aktiva inspektionsfasen startade.. Sverige genomförde tre pilotinspektioner varefter checklistan justerades. Projektgruppens erfarenhet av att göra pilotinspektioner är positiv då vi upplever att oklarheter i checklistan identifierades och åtgärdades innan alla länder startade sina inspektioner.

Antalet kontrollerade företag och produkter skiljer sig länderna emellan, men alla frågor i den gemensamma checklistan (se bilaga 1) har kontrollerats och rapporterats (förutom att Danmark inte rapporterat in frågor som rör SDB). Dessutom har respektive land haft möjlighet att kontrollera andra regler t.ex. registrering enligt REACH och anmälan till nationellt Produktregister men detta har inte rapporterats inom detta projekt. Se mer under respektive lands resultat (se kapitel 4).

En WS för projektgruppen genomfördes efter den aktiva fasen för att diskutera resultatet och gemensamt skriva slutrapporten. Innan WS hade projektdeltagarna från respektive land i uppgift att se till att de nationella resultaten var rapporterade samt att en kortare sammanfatt- 
ning och resultat från respektive land lagts upp på projektplatsen. Projektdeltagare från Norge, Sverige och Danmark träffades på Klif i Oslo under 2 dagar för att gemensamt gå igenom resultatet och identifiera viktiga resultat att belysa i rapporten. Arbetet med att skriva rapporten fördelades mellan deltagarna och vi gick sedan igenom alla delar i rapporten tillsammas. Det här är ett nytt sätt att arbeta på inom de nordiska sammarbetsprojekten som vi upplever som både positivt och effektivt för att sammanfatta och slutföra projektet inom planerad tid. 


\section{Resultater og konklusjoner}

\subsection{Samlet resultat og konklusjon}

I prosjektet er det kontrollert totalt 164 kjemiske produkter (stoff og stoffblandinger), fordelt på 45 virksomheter.

Figur 1. Figuren viser antall virksomheter, stoffer og stoffblandinger som er kontrollert i prosjektet, fordelt på land

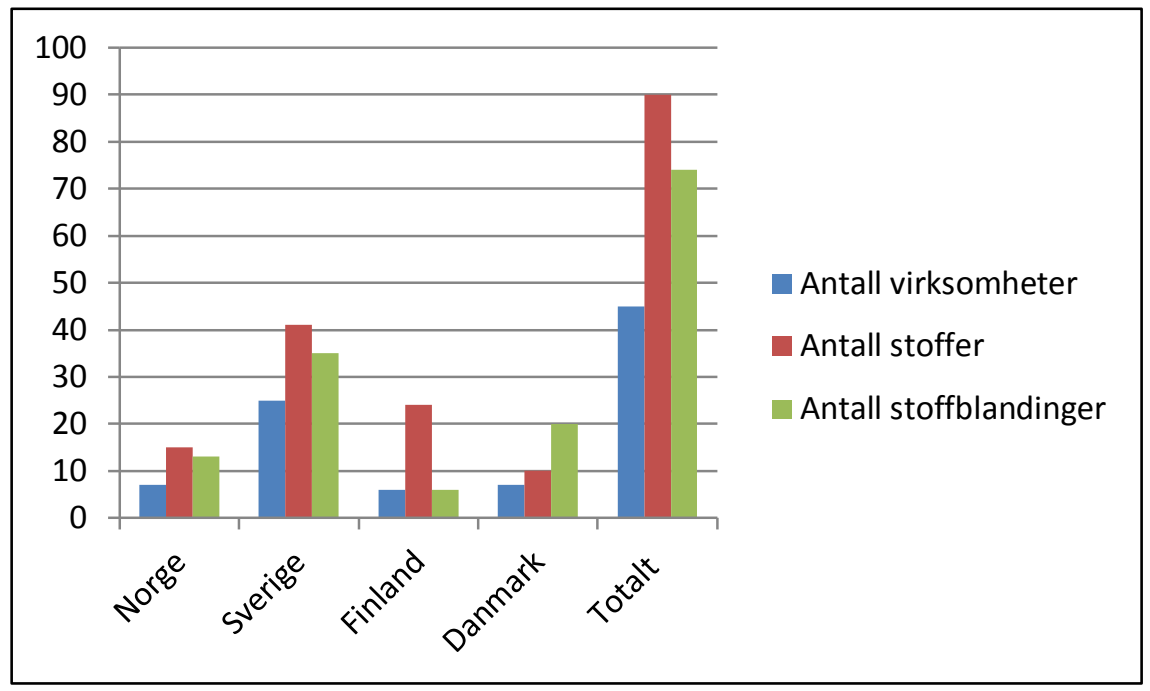

CLP-klassifisering har vært obligatorisk for rene stoffer fra 1. desember 2010. For stoffblandinger er det imidlertid frivillig å klassifisere etter CLP fram til 1. juni 2015.

I prosjektet har vi undersøkt hvor mange virksomheter som har valgt å gå over til CLP-klassifisering for sine stoffblandinger. Resultatet viser at i 27 av 30 kontrollerte virksomheter er de godt i gang eller har fullstendig gått over til CLP-klassifisering for stoffblandinger. Forklaringen på hvorfor de har gjort det er flere:

- De er en del av et globalt konsern som har lagt en felles plan for overgangen til CLP.

- De har kjøpt inn ny programvare for klassifisering og merking etter CLP. 
- De har klassifisert stoffene etter CLP, og det er derfor naturlig å gå over til CLP-klassifisering for stoffblandingene.

- De fleste virksomhetene har mange flere stoffblandinger enn stoffer og de trenger derfor tid for å CLP-klassifisere alle stoffblandingene innen fristen 1. juni 2015.

\section{Notifisering}

I prosjektet har vi kontrollert om virksomhetene har plikt til å notifisere til ECHA i henhold til artikkel 39 og 40 i CLP. Vi fant at 16 av de kontrollerte virksomhetene hadde plikt til å notifisere, og kun 3 av disse hadde ikke oppfylt notifiseringsplikten. Mange virksomheter opplyste at de velger å kjøpe kjemikalier fra EU for å slippe både REACH-registrering og notifisering.

\section{Manglende CLP klassifisering kun for ett stoff}

Det ble kontrollert 90 stoffer i prosjektet og kun ett stoff manglet CLPklassifisering. Siste frist for å klassifisere stoffer etter CLP var 1. desember 2012, og kontrollene ble gjennomført i januar og februar 2013. At kun ett av de kontrollerte stoffene ikke var CLP-klassifisert er derfor et svært bra resultat.

For alle de undersøkte stoffene, med en harmonisert klassifisering, stemte den oppgitte klassifiseringen i sikkerhetsdatabladet med klassifisering i CLP vedlegg VI (stofflisten).

\section{Klassifisering for stoffblandinger}

Kontroll av klassifiseringen for stoffblandinger viser at av 74 kontrollerte stoffblandinger, har 10 feil klassifisering ut fra oppgitte innholdsstoffer og 10 har en uavklart klassifisering når denne rapporten skrives (figur 2).

Årsaken til den uavklarte klassifiseringen er blant annet at det mangler dokumentasjon for viskositet og at konsentrasjonsintervallene i avsnitt 3 i SDS er for vide, noe som medfører strengere klassifisering enn oppgitt i SDS når høyeste verdi brukes.

På bakgrunn av resultatene, ser vi at det er mer utfordrende for virksomhetene å klassifisere stoffblandinger enn stoffer etter de nye kriteriene for klassifisering av blandninger, blant annet på grunn av nye konsentrasjonsgrenser for øyeirritasjon og reprotoksisitet og endring av kriterier for miljøklassifisering og akutt toksisitet. 
Figur 2. Figuren viser antall kontrollerte stoffblandinger med henholdsvis korrekt, feil og uavklart klassifisering

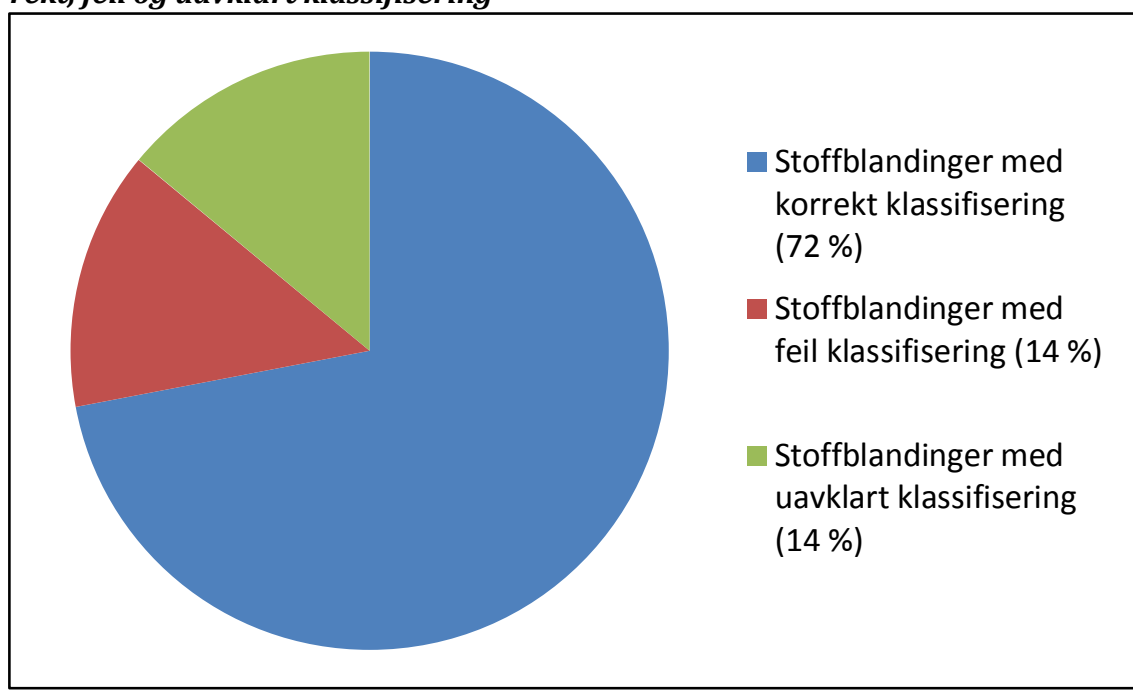

\section{Kontroll av sikkerhetsdatablader (SDS)}

I prosjektet er det kontrollert om sikkerhetsdatabladet er i henhold til revidert vedlegg II til REACH (453/2010) og om avsnitt 2, 3 og 12 i sikkerhetsdatabladet inneholder korrekte opplysninger. Dette er kontrollert i Sverige, Finland og Norge. I Danmark er det Arbeidstilsynet som har myndighetsansvaret for SDS, og datablader har derfor ikke blitt kontrollert siden det er Miljøstyrelsen som er med i dette prosjektet.

Totalt 134 SDS er kontrollert og alle bortsett fra 3 er i henhold til revidert vedlegg II til REACH (EU forordning $\mathrm{nr} 453 / 2010$ ).

Sett i lys av at inspeksjonene er gjennomført kort tid etter at overgangstiden for revidert vedlegg II til REACH er ferdig (1. desember 2012), er resultatene veldig bra. 
Figur 3. Figuren viser antall kontrollerte SDS, antall SDS med riktig format og antall SDS med riktig format men med feil

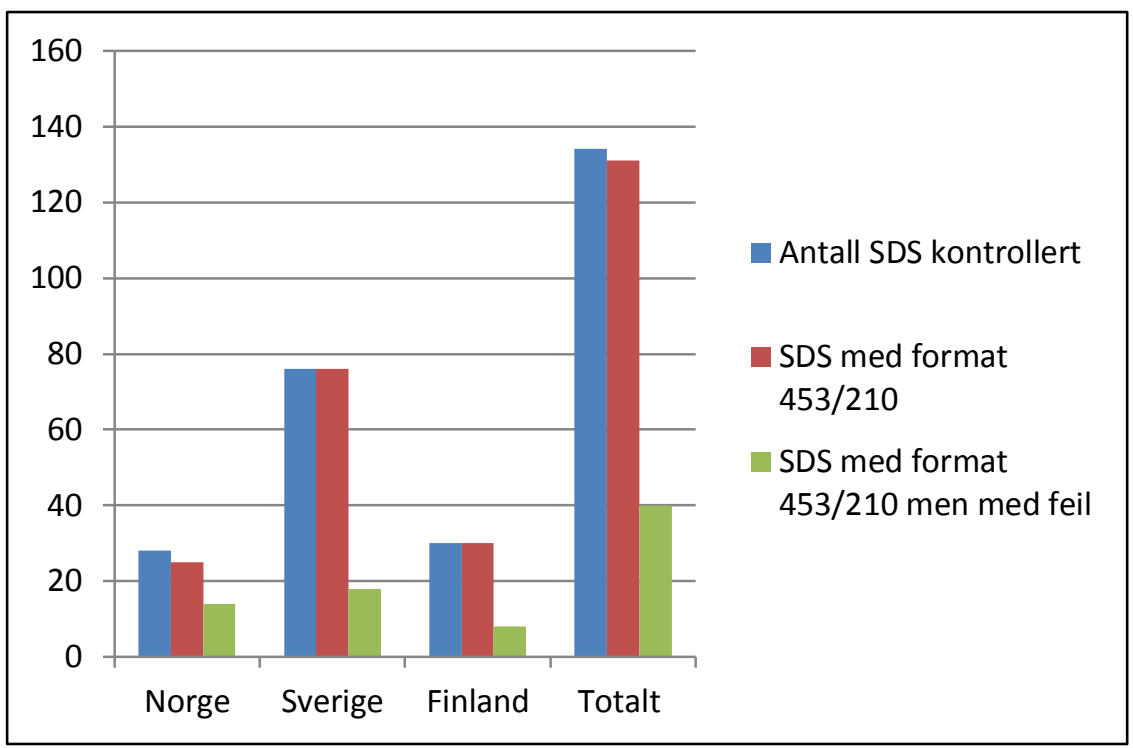

Figur 4. Figuren viser prosentvis andel av SDS med feil

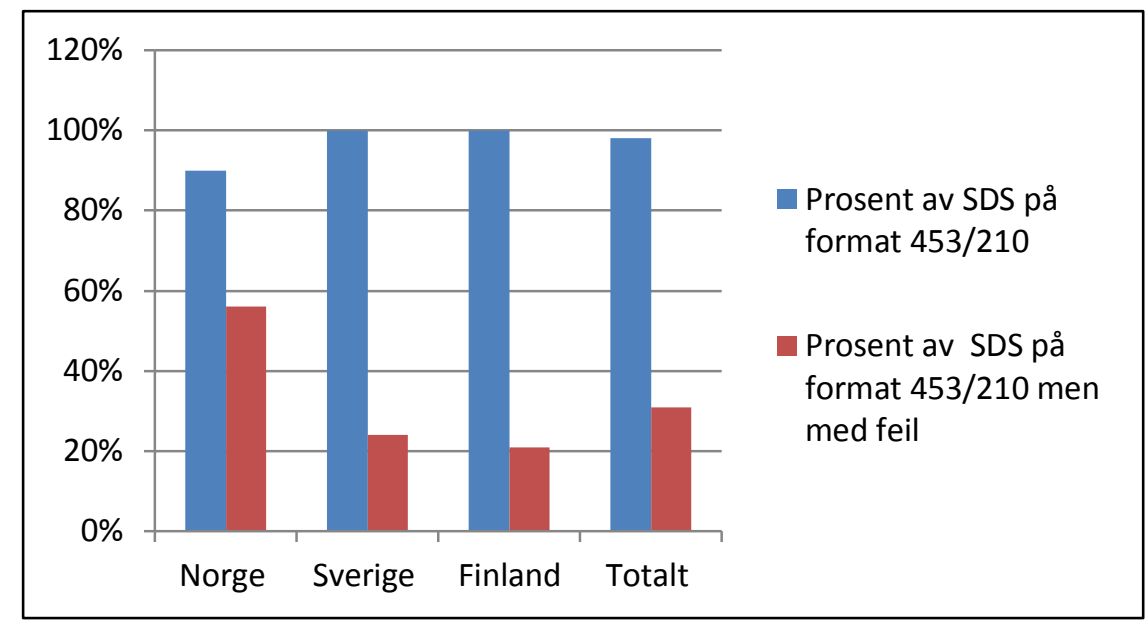

\section{Kontroll av merkeetiketter}

I prosjektet er det kontrollert 138 etiketter totalt, fordelt på 76 i Sverige, 24 i Danmark, 25 i Finland og 13 i Norge. Antallet etiketter totalt er noe lavt og svært variabelt fra land til land, og tallene er derfor noe usikre. 
Figur 5. Figuren viser antall kontrollerte merkeetiketter og antall med feil

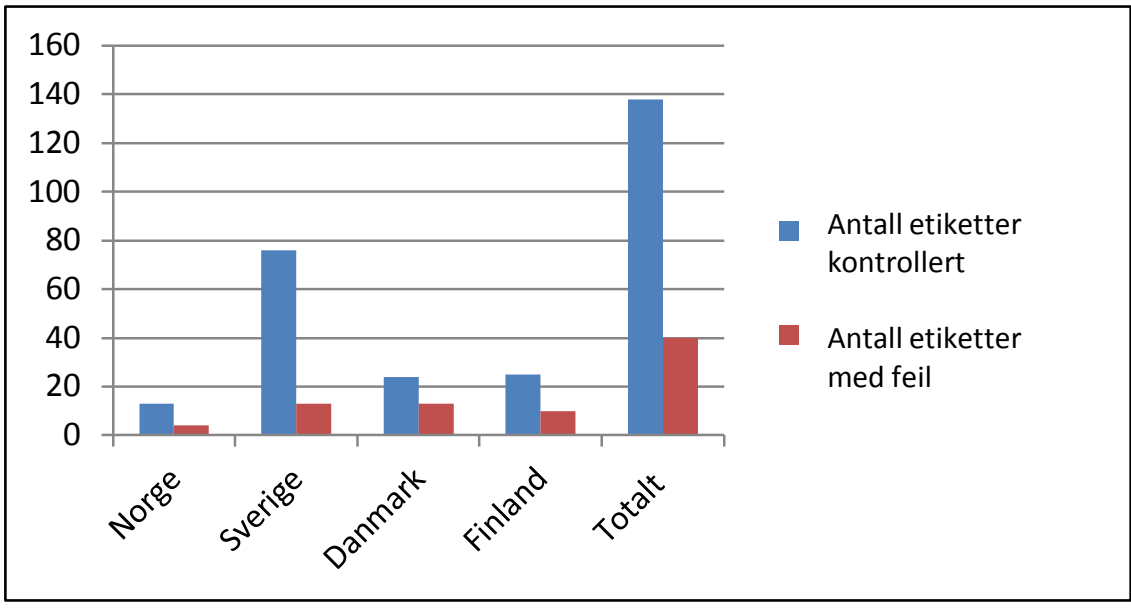

Figur 6. Figuren viser prosent etiketter med feil fordelt på land

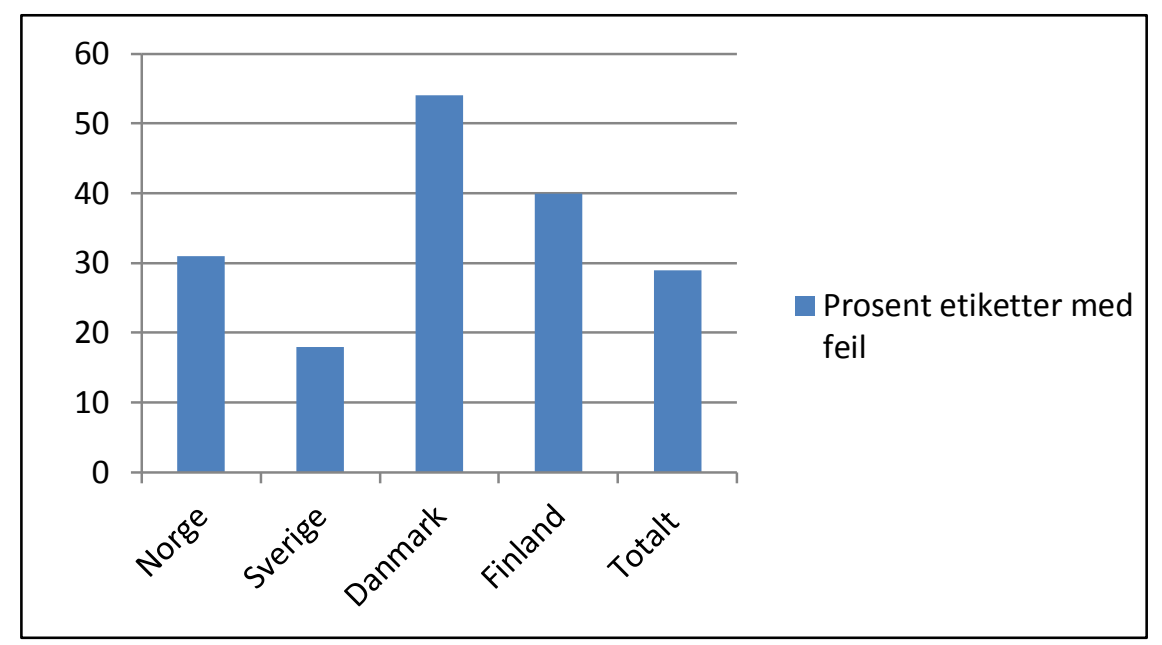

I CLP er det krav om at merketiketten skal være tydelig og lettlest, at den skal være på nasjonalt språk og inneholde blant annet produktnavn (produktidentifikator), kontaktopplysninger, faresetninger (H-setninger), sikkerhetssetninger (S-setninger) og farepiktogram.

Fordelingen i figur 7 viser at vi har funnet flest feil ved farepiktogram, faresetninger og sikkerhetssetninger, mens mangelfulle kontaktopplysinger og dårlig lesbarhet også er feil som vi finner.

Siden antall kontrollerte etiketter er svært variabelt fra land til land, er det vanskelig å trekke en felles konklusjon ut fra de tallene som vi har funnet. 
Figur 7. Figuren viser kontrollerte etiketter med oversikt over feil

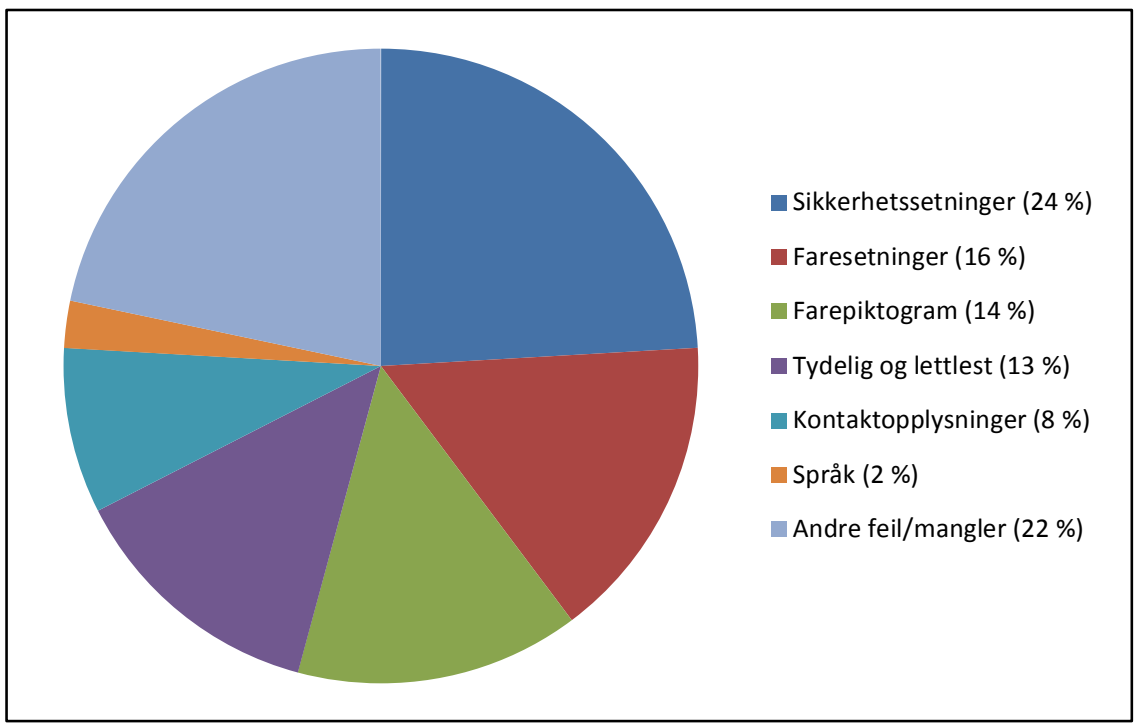

\section{Barnesikret lukning og følbar advarselsmerking}

Det er flere produkter enn tidligere som har fătt krav til barnesikret lukning og følbar advarselsmerking ved overgangen til CLP, blant annet på grunn av endrete kriterier for klassifisering (eks etsende, aspirasjonstoksisk, akutt toksisitet). Vi tok derfor med noen spørsmål om barnesikret lukning og følbar advarselsmerking i sjekklisten, men kun et fătall av de kontrollerte virksomhetene solgte kjemikalier direkte til forbrukere og spørsmålene var derfor ikke relevante for flertallet av virksomhetene.

Totalt 7 virksomheter hadde stoffer/stoffblandinger med barnesikret lukning og følbar advarselsmerking, og alle de kontrollerte produktene oppfylte kravene.

\section{M-faktor}

M-faktor (multiplikasjonsfaktor) brukes ved miljøklassifisering av stoffblandinger, og er nytt i CLP. Det er ikke et krav i CLP eller REACH art 31/vedlegg II til å oppgi M-faktor i SDS, men det er en sterk anbefaling i ECHA's veiledning for SDS om at virksomhetene bør gjøre det. Se "Guidance on the compilation of the safety data sheets", kap 4.3 Section 3.

Av de kontrollerte virksomhetene som hadde stoffblandinger med miljøklassifering, var det ca $75 \%$ av virksomhetene som ikke oppga Mfaktor i SDS. 
Tabel 1. Antall virksomheter som oppgir M-faktor i SDS

\begin{tabular}{lrrr}
\hline Land & M-faktor oppgitt & M-faktor ikke oppgitt & Ikke relevant \\
\hline Norge & 1 & 1 & 5 \\
Sverige & 3 & 6 & 16 \\
Finland & & 6 & 21 \\
Totalt antall virksomheter & 4 & 13 & 21 \\
\hline
\end{tabular}

Siden M-faktor er viktig for å kunne miljøklassifisere stoffblandinger korrekt, mener prosjektgruppen at det er en stor mangel i regelverket at det ikke er obligatorisk å oppgi M-faktor i SDS.

\subsubsection{Resultater fra Sverige}

De svenska företag som inspekterades inom projektet valdes ut med hjälp av uppgifter från Kemikalieinspektionens produktregister. En lista på företag som enligt uppgifter i produktregistret rapporterat att de klassificerar och märker sina produkter (ämnen och/eller blandningar) enligt CLP togs fram. Sverige valde att inspektera flera stora företag som finns representerade även i övriga nordiska länder och där huvudkontoret är lokaliserat i Sverige. Även flera mindre företag valdes ut för att kontrollera att de har klarat av övergången till CLP och nya säkerhetsdatablad.

Kemikalieinspektionen har inspekterat 25 företag som tillverkar eller importerar kemiska produkter som de sedan släpper ut på den svenska marknaden. 23 av företagen inspekterades på plats (besöksinspektioner) och två kontrollerades brevledes. Endast ett av företagen tillverkade ämnen, 8 företag importerade ämnen och resterande var enbart nedströmsanvändare (DU) eller distributörer. I Sverige kontrollerades produktinformationen för 41 blandningar och 35 ämnen, totalt 76 produkter, som företagen själva valt ut att redovisa innan besöket.

Vid inspektionerna kontrollerades, förutom de frågor om CLP som är gemensamma i det nordiska projektet, även andra relevanta delar av kemikalielagstiftningen som KemI normalt kontrollerar vid tillsynsbesök. Exempelvis kontrollerades även hur företagen uppfyller sina skyldigheter vad gäller registrering enligt Reach, anmälan till produktregistret, nationella regler om överlåtelsetillstånd och övriga avsnitt i säkerhetsdatabladen (endast avsnitt 2, 3 och 12 rapporteras in i projektet).

Samtliga ämnen som kontrollerades (35) var klassificerade och märkta enligt CLP. Alla ämnen med harmoniserad klassificering var korrekt klassificerade enligt bilaga VI till CLP. Endast en av de kontrollerade blandningarna innehöll ett ämne med felaktig klassificering enligt Annex VI, tabell 3.1 (CLP). 
För 5 av de kontrollerade blandningarna (41) var CLPklassificeringen inkorrekt och för 9 blandningar var det oklart om klassificeringen var riktig. Resultaten tyder på att vissa företag har problem med att övergå till att klassificera blandningar enligt CLP vilket kan bero på skillnader i kriterierna mellan de båda klassificeringssystemen. Som exempel kan nämnas att några produkter hade en felaktig CLPklassificering på grund av att gränserna för klassificering för allvarliga ögonskador och reproduktionstoxicitet sänkts i och med CLP.

Bland de svenska företagen uppgav majoriteten (19) av företagen att de frivilligt övergått till att tillämpa CLP även för blandningar. Många uppgav att anledningen till att man inte utnyttjat övergångsperioden för blandningar är att de vill undvika att använda två system för klassificering och märkning samtidigt. Många hade en mjukvara som klarade av att ta fram produktinformation enligt CLP för både ämnen och blandningar vilket förenklade övergången till CLP. Andra däremot uppgav att de hade problem att övergå till CLP för sina blandningar just på grund av att deras mjukvara eller printer inte klarade av detta.

Sammanlagt 13 (av 76) produkter hade brister i märkningen (t.ex. brister i faro- och skyddsangivelser, avsaknad av faropiktogram).

Samtliga kontrollerade produkter hade säkerhetsdatablad utformade enligt det nya formatet (453/2010), men 18 av dessa innehöll brister under avsnitt 2, 3 eller 12 (t.ex. dubbel märkning under avsnitt 2).

Många av de svenska företag som inspekterades för in sina produkter/råvaror från europeiska leverantörer och omfattas därför inte av kravet på registrering och anmälan till klassificerings- och märkningsregistret. Endast 6 av de inspekterade företagen omfattas av skyldigheten att anmäla sina tillverkade eller importerade ämnen till ECHA:s klassificerings- och märkningsregister. Alla dessa företag uppfyllde denna skyldighet för de kontrollerade ämnena. Ett av företagen hade två ämnen vars klassificering i säkerhetsdatabladet avvek från den som anmälts till registret. Denna avvikelse berodde på att man inom konsortiet beslutat att ändra ämnenas klassificering i slutet av 2012 (till Asp. Tox. 1) och den nya klassificeringen hade inte uppdaterats i klassificerings- och märkningsregistret. Företaget uppmanades att uppdatera uppgifterna till klassificerings- och märkningsregistret utan onödigt dröjsmål.

De svenska inspektörerna hade påfallande ofta problem med att logga in i RIPE för att kontrollera företagens notifieringar, vilket försvårade arbetet. Många företag uppgav att deras ämnen notifierats tidigare $\mathrm{i}$ leverantörskedjan, vilket är svårt att kontrollera då man inte kan koppla notifieringar i Inventory till ett specifikt företag. Vi har inte begärt att få 
underlag, t.ex. submission number, som bekräftar att företaget eller deras leverantörer verkligen har anmält ämnena.

För 6 av företagen saknades uppgift om M-faktor i säkerhetsdatabladet trots att blandningen innehöll ämnen klassificerade i kategori Aquatic Acute 1 eller Chronic 1. Utan uppgift om M-faktor eller data från toxicitetstester under avsnitt 12 kan man inte alltid säkert avgöra om en blandning ska klassificeras för miljöfara eller inte. Att ange en M-faktor under avsnitt 2 eller 3 i SDB är inte ett krav enligt reglerna, men rekommenderas starkt enligt vägledningen. Tre företag uppgav M-faktor i SDB.

För 21 av företagen påträffades brister som ledde till påpekanden eller anmodan att inkomma med rättelse. Observera att detta även gäller annat som kontrollerats vid inspektionerna, men som inte varit en del av CLP-projektet (inte rapporterats in). Ett företag anmäldes för misstanke om brott mot svenska bestämmelser om tillstånd för överlåtelse av särskilt farliga kemiska produkter.

Av de kontrollerade företagen så var det endast 5 stycken som redovisat konsumenttillgängliga produkter med krav på barnskyddande förslutning och taktil märkning. Glädjande nog hittade vi inga brister alls när det gäller barnskydd och taktil märkning.

Sammanfattningsvis visar de svenska resultaten att företagen har lyckats väl i övergången till CLP och det nya formatet av SDB då inga allvarliga brister noterats.

\subsubsection{Resultater fra Danmark}

Kemikalieinspektionen har kontrolleret udvalgte virksomheders notificeringer af stoffer importeret fra ikke-EU-lande til ECHA, samt klassificering og mærkning af stoffer og blandinger, hvori stofferne indgår. Stofferne og blandingerne udvælges som stikprøver.

I Danmark har Kemikalieinspektionen valgt at føre et totaltilsyn, når vi er på virksomhederne. Dvs. inspektionen fører tilsyn med andre relevante områder under et tilsynsbesøg. I forbindelse med denne kampagne blev virksomhedernes registreringsforpligtelser i forhold til REACHforordningen derfor også kontrolleret.

Virksomhederne blev udvalgt på baggrund oplysninger om import fra SKAT samt ud fra ECHA's liste over firmaer, der havde præ-registreret stoffer med registreringsdeadline i 2010, men ikke efterfølgende havde foretaget en registrering.

Da kampagnen går ud på at kontrollere notificeringer, forsøgte Kemikalieinspektionen at finde virksomheder med import fra uden for EU, sådan at virksomhederne havde denne forpligtigelse. Det viste sig dog at 
mange danske virksomheder køber deres råvarer hos europæiske leverandører for at undgå registrerings- og notificeringsforpligtigelserne. Dette er i tråd med, hvad tidligere kampagner også har vist (REF2).

Virksomhederne havde for en sikkerheds skyld præ-registreret alle de stoffer, som virksomhederne importerede eller som de forventede at skulle importere på et tidspunkt. Efterfølgende har de så vurderet, at enten så skulle de ikke bruge stofferne alligevel, eller også havde de som nævnt ovenfor valgt at få dem fra europæiske leverandører.

Dette er den primære årsag til, at der figurerer disse præ-registreringer, som firmaerne reelt ikke er forpligtigede til at registrere. Virksomhederne blev i den forbindelse gjort opmærksomme på, at de har en forpligtigelse til at opdatere de oplysninger, som de har indleveret til ECHA.

I Danmark blev der i alt kontrolleret syv virksomheder, heraf var tre stofimportører, en var producent og tre var downstream-brugere (DU'ere).

I alt blev der kontrolleret 10 stoffer og 20 blandinger. Heraf var der en virksomhed, som ikke havde overholdt sin notificeringsforpligtigelse. Der blev konstateret uoverensstemmelser mellem den harmoniserede klassificering kontra angiven klassificering i SDS i to tilfælde. Hvis man sammenholdt oplysningerne i SDS pkt. 3.2 om blandingernes sammensætning med SDS pkt. 2.1 om faremærkning, var der tre uoverensstemmelser.

Med hensyn til klassificeringen af de kontrollerede blandinger, blev der konstateret fejl i tre af blandingernes klassificering, mens en er uafklaret. Dette medførte, at der også var fejl i faremærkningen af de tre blandinger.

Håndhævelsen af overtrædelserne var at Miljøstyrelsen gav en indskærpelse til virksomhederne om, at blandingerne skulle lovliggøres. Et firma valgte på den baggrund at lade blandingen udgå af deres sortiment, mens de resterende valgte at omklassificere og på den baggrund opdatere faremærkningen i form af nye fareetiketter.

Kemikalieinspektionens observerede ved gennemgangen af virksomhedernes fareetiketter, at ECHA's anbefaling omkring, at tomme farefelter ("empty diamonds") på fareetiketterne bliver blokket helt ud med sort, ikke følges. Virksomhederne skriver i stedet "no symbol" i de tomme farefelter. Kemikalieinspektionen har henstillet overfor de berørte virksomheder, at ECHA's anbefaling følges.

\subsubsection{Resultater fra Finland}

De finska företag som inspekterades inom projektet valdes ut med hjälp av uppgifter från Säkerhets- och kemikalieverkets (Tukes) produktregister. Till projektet valdes sådana företag, som enligt produktregistret klassificerar och märker enligt CLP-förordningen. Det var oväntad svårt att hitta 
sådana företag som också har marknad i övriga nordiska länderna och som inte redan hade valts ut för inspektion i de andra nordiska länderna!

Tukes har inspekterat sex företag som släpper ut kemiska ämnen och blandningar på marknaden i Finland och andra nordiska länder. Företagen kontrollerades brevledes. Av dessa företag var två tillverkare, två nedströmsanvändare och två distributörer. I Finland kontrollerades produktinformationen för 24 ämnen och 6 blandningar, som företagen själva valde ut.

Samtliga ämnen som kontrollerades var klassificerade och märkta enligt CLP. Alla ämnen med harmoniserad klassificering var korrekt klassificerade enligt bilaga VI till CLP. Blandningarna var också klassificerade och märkta enligt CLP och alla ämnen i blandningarna med harmoniserad klassificering var korrekt klassificerade enligt bilaga VI till CLP. För två av de kontrollerade blandningarna var det oklart om klassificeringen var korrekt.

Samtliga kontrollerade produkter hade säkerhetsdatablad utformade enligt det nya formatet (EU) N:o 453/2010. Ett företag som släpper ut på marknaden lampolja och tändvätska för grillkol hade inte uppgett i punkt 2.2. av SDS faroangivelser enligt REACH bilaga XVII punkt 3. Ett företag hade på första sidan av SDS först märkningarna för transportfaror och sedan enligt CLP, men märkningarna enligt CLP var inte alltid i punkt 2.2.

Bara två av de inspekterade företagen (tillverkare) var notifikationspliktiga enligt CLP.

I samband med projekts genomförande framkom att information om ämnens klassificering och märkning inte nödvändigtvis fanns i RIPE fastän informationen hade insänts i samband med ämnets registrering.

Inom projekt uppdagades vissa avvikelser från kraven gällande märkningar (bl.a. farosymbolens storlek), säkerhetsdatablad och klassificering av blandningar. Tukes kommer att kontakta ifrågavarande företag i syfte att åtgärda felen.

\subsubsection{Resultater fra Norge}

I Norge ble det kontrollert totalt 7 virksomheter. Siden formålet med prosjektet var å undersøke om stoffer var klassifisert og merket i henhold til CLP, valgte vi å søke i Produktregisterets database og tilsynsdatabasen RIPE for å finne kontrollobjekter. Vi benyttet også ECHA sine offentlige søkeverktøy og internett. Hos alle virksomhetene ble det også kontrollert andre temaer enn de som var beskrevet i sjekklisten til prosjektet, blant annet registreringsplikten til REACH.

Alle tilsynene ble varslet på forhånd og gjennomført som besøk hos virksomhetene. Flere av virksomhetene hadde helse-, miljø- og sikkerhetsavdeling lokalisert $i$ et annet nordisk land og kun en salgs- og mar- 
kedsføringsavdeling i Norge. Noen av disse valgte derfor å ha en representant fra den nordiske HMS-avdeling tilstede under tilsynet.

Flertallet av virksomhetene kjøpte kjemikaliene fra leverandører i Europa og solgte videre. De baserte seg på at leverandøren klassifiserte og merket og utarbeidet sikkerhetsdatablader på nasjonalt språk. Kun i de tilfellene der leverandøren ikke kunne levere et oversatt sikkerhetsdatablad, utarbeidet de kontrollerte virksomhetene SDS selv.

Det ble ikke avdekket brudd på registreringsplikten til REACH. 4 av de 7 kontrollerte virksomhetene hadde plikt til å notifisere (CLP art 48), og en av virksomhetene hadde ikke oppfylt notifiseringsplikten.

Ett av de kontrollerte stoffene manglet klassifisering etter CLP.

Vi kontrollerte stoffblandinger i 6 av de 7 virksomhetene og alle hadde frivillig gått over til CLP-klassifisering og merking av disse. Alle de kontrollerte stoffblandingene var riktig klassifisert ut fra opplysninger gitt i sikkerhetsdatabladene.

Kun ett av de kontrollerte stoffene og to av de kontrollerte stoffblandingene hadde sikkerhetsdatablad på gammelt format. De øvrige hadde oppdatert SDS i henhold til revidert vedlegg II i REACH (453/2010). Flere av sikkerhetsdatabladene manglet imidlertid obligatoriske underrubrikker. Norge hadde ikke implementert revidert vedlegg II til REACH (forordning 453/2010) da kontrollene ble gjennomført.

Det ble kontrollert få fareetiketter, blant annet fordi noen av tilsynene foregikk i kontorlokalene til distributører som ikke hadde varelager eller elektroniske etiketter tilgjengelig på stedet. Av de kontrollerte etikettene var det feil ved ca $30 \%$.

Det var ingen av de kontrollerte virksomhetene som solgte kjemikalier til privat bruk, og derfor var ikke kontroll av barnesikker lukning, følbar merking relevant. Ingen av de kontrollerte virksomhetene solgte kjemikalier via nettbutikk. 


\section{Summary and conclusion}

The aim of the project has been to control whether chemicals have been correctly classified and labelled in accordance with the Classification, Labelling and Packaging (CLP) Regulation.

The CLP Regulation came into force in 2010. All chemicals that are on the market shall be classified and labelled in accordance with CLP from 1 December 2012. Mixtures shall be classified and labelled in accordance with CLP from 2015, although CLP can be used voluntarily for such mixtures prior to the deadline.

The project has also controlled the notification of chemicals (CLP art. 40), the classification and labelling of chemical mixtures, and new demands to safety data sheets (SDS) in regulation 453/2010 (revised Annex II of REACH).

The project was carried out from May 2012 to June 2013. The participants were Sweden, Denmark, Finland, and Norway, with the project committee comprising two representatives from each country. Two project meetings were held: an inaugural meeting in May 2012, and a twoday workshop in April 2013. All other communication has taken place through e-mail and a joint online project folder.

A total of ninety chemicals were controlled in the four countries, with only one chemical lacking CLP classification. This is a highly satisfactory result.

Most of the enterprises where we controlled chemical mixtures have begun to classify and label such mixtures according to CLP, though not all of them had finalized the process of implementing CLP for their entire product line. This is primarily because many suppliers have a broad range of products that they distribute to many countries, and it takes time to develop safety data sheets and labels in a variety of languages.

According to CLP, chemicals that have a harmonized classification that is, a classification that the EU/EEA countries have agreed on - shall use that classification. Our results show that the enterprises have used the correct, harmonized classification for all the controlled chemicals. Likewise, the enterprises used the correct, harmonized classification for $80 \%$ of the chemicals in the chemical mixtures we controlled. 
In regard to notifying the European Chemicals Agency (ECHA) of the classification and labelling of chemicals, our results indicate that most of the controlled enterprises choose to buy from suppliers in the EU in order to avoid registration in accordance with REACH and notification in accordance with CLP.

Out of a total of 134 controlled safety data sheets (SDS), only three were not in line with the revised Annex II of REACH (regulation $453 / 2010$ ). However, these three sheets were found in Norway, where the revised Annex II had yet to be implemented at the time of control. Safety data sheets were not controlled in Denmark, since another monitoring agency than the Danish Environmental Protection Agency is primarily responsible for controlling safety data sheets in Denmark.

A total of 138 labels were controlled. The results indicate that certain chemical mixtures were not correctly classified in line with CLP. This suggests that the enterprises might find it challenging to classify mixtures per the new rules.

The project results indicate that all of the controlled enterprises have classified and labelled their chemicals in accordance with CLP. Though the process of classifying and labelling chemical mixtures per CLP is thus well underway in all four Nordic countries, our results reveal that some of the chemical mixtures have been incorrectly classified and labelled. This suggests that the new rules might be somewhat more challenging for chemical mixtures than for individual chemicals.

All in all, the results from the inspection project show that the enterprises have made a successful transition to CLP and the new safety data sheet format, since no serious deficiencies were uncovered. 


\section{Definitioner}

\section{CLP}

CLP (forordning 1272/2008) er forkortelsen for Classification, Labelling and Packaging, og er den nye forordning, der trinvis erstatter stofdirektivet (67/548/EØF) og præparatdirektivet (99/45/EF). Stoffer og blandinger skal efterhånden som de forskellige dele af forordningen træder i kraft klassificeres og mærkes efter reglerne i CLP.

\section{ECHA}

Det Europæiske Kemikalieagentur i Helsinki. Agenturet står bl.a. for den praktiske håndtering af registreringen, samt vurderingen af testforslag og kontrol af, om registreringerne lever op til kravene. Agenturet sår også for den praktiske administration af godkendelsesordningen og for udfærdigelse af vejledninger til industri og myndigheder.

Notificering af klassificering til industrilisten anmeldes også til ECHA.

\section{C\&L Inventory (Industrilisten DK, Klassificerings- och} märkningsregisteret SE, Klassifiserings- og merkingsdatabasen NO) En database med fortegnelse over alle klassificering og mærkning notificeret hos ECHA.

\section{Notificering}

Importører eller producenter af stoffer klassificeret som farlige skal senest 1 måned efter stoffet markedsføres notificere (anmelde) klassificeringen til ECHA.

\section{SDS (SDB)}

SDS er en forkortelse for Safety Data Sheet - også kaldet et sikkerhedsdatablad.

\section{REACH}

REACH (forordning 1907/2006) er EU's grundlæggende kemikalielovgivning, der skal sikre, at kemikalier bruges forsvarligt, med minimal risiko for sundhed og miljø. Forkortelsen står for Registration, Evaluation and Authorisation of Chemicals (Registrering, vurdering og godkendelse af kemikalier). 


\section{Stof}

Et grundstof ellet forbindelser heraf, som er naturligt eller industrielt fremstillet

\section{Stofblanding}

En blanding eller opløsning, der er sammensat af to eller flere stoffer

\section{Down Stream bruger (Etterfølgende bruker)}

Enhver fysisk eller juridisk person etableret i Fællesskabet, bortset fra producenten eller importøren, som anvender et stof som sådan eller i en blanding som led i sine industrielle eller erhvervsmæssige aktiviteter. En distributør eller en forbruger er ikke en down stream bruger

\section{Producent/Tillverkare/Framstiller/Produsent - rene stoffer}

Enhver fysisk eller juridisk person etableret i fællesskabet, der fremstiller et stof inden for Fællesskabet

\section{Importør}

Enhver fysisk eller juridisk person etableret i Fællesskabet, der er ansvarlig for import

\section{Distributør}

Enhver fysisk eller juridisk person etableret i Fællesskabet, herunder en detailhandler, der kun opbevarer og markedsfører et stof som sådan eller i en blanding for tredjeparter

\section{DSD Stofdirektivet/Ämnesdirektivet}

Rådets direktiv 67/5487EøF af 27. juni 1967 om tilnærmelse af lovgivning om klassificering, emballering og etikettering af farlige stoffer

\section{DPD Præparatdirektivet/Preparatdirektivet}

Europa-Parlamentets og Rådets Direktiv 1999/45/EF af 31. maj 1999 om indbyrdes tilnærmelse af medlemsstaternes love og administrative bestemmelser om klassificering, emballering og etikettering af farlige præparater. 


\section{Bilag 1: Sjekkliste}

\subsection{Informasjon om kontrollen}

Virksomhetens navn:

Dato for inspeksjon:

Land:

Inspektør:

Antall stoff og/eller stoffblandinger kontrollert i prosjektet:

1. antall stoff:

2. antall stoffblandinger:

3. har virksomheten frivillig klassifisert og merket stoffblandinger $i$ henhold til CLP:

$\square$ Ja

$\square$ Nei

\subsection{Kontroll av notifisering (art. $39 \& 40$ )}

Plikten til å notifisere gjelder kun fremstiller og/eller importør av farlig(e) stoff(er) eller stoffer i stoffblandinger som plasseres på markedet. En tredjepart kan på vegne av fremstiller/importør notifisere, men da må virksomheten (fremstiller/importør) kunne dokumentere dette.

2.1. Har virksomheten plikt til å notifisere?

$\square \mathrm{Ja}$

$\square$ Nei, gå til seksjon 3: Kontroll av klassifisering 
2.2 Har virksomheten notifisert de kontrollerte stoffene eller stoffer i stoffblandinger?

\section{$\mathrm{Ja}$}

$\square$ Nei, ___ av de kontrollerte stoffene var ikke notifisert.

$\square \mathrm{Nei}, \ldots$ av de kontrollerte stoffblandingene inneholder stoffer som ikke er notifisert.

$\square$ Ingen av de kontrollerte stoffene eller stoffene i stoffblanding(ene) har notifiseringsplikt, selv om virksomheten har en slik plikt for andre stoffer, gå til seksjon 3, Kontroll av klassifisering.

2.3. Stemmer notifikasjonsopplysninger for de kontrollerte stoffer/ stoffer i stoffblandingene med opplysninger i RIPE i forhold til klassifisering;

$\square$ Ja

$\square$ Nei

\subsection{Kontroll av klassifisering}

\section{Merknad til inspektør: Kontroll av selvklassifiserte stoffer er valgfritt i dette prosjektet, og skal ikke rapporteres.}

3.1 Klassifisering av stoffer:

Alle stoffer skal være klassifisert i henhold til både CLP og DSD (67/548/EøS) i SDS, men merkes og emballeres kun etter CLP (art. 61.3).

3.1.1. Har de kontrollerte stoffene en CLP klassifisering?

$\square$ Ja

$\square$ Nei, av de kontrollerte stoffene er ikke klassifisert etter CLP.

3.1.2. Er de kontrollerte stoffene klassifisert riktig i henhold til harmonisert klassifisering i CLP Annex VI (gjelder kun for stoffer med harmonisert klassifisering)?

$\mathrm{Ja}$

Nei, av de kontrollerte stoffene har feil harmonisert klassifisering. 


\subsection{Klassifisering av stoffblandinger:}

Dersom CLP benyttes for stoffblandinger skal klassifisering være etter både CLP og DPD (1999/45/EØS) frem til 2015, mens merking og emballering kun etter CLP (art. 61.2).

3.2.1. Stemmer harmonisert klassifisering for inngående stoffer $i$ avsnitt 3 i SDS med Annex VI til CLP?

$\square$ Ja, riktig i henhold til tabell 3.2 i Annex VI (DSD).

$\mathrm{Nei}$ av de kontrollerte stoffblandingene har inn holdsstoffer med feil klassifisering i henhold til tabell 3.2 i Annex VI (DSD).

$\square$ Ja, korrekt i henhold til tabell 3.1 i Annex VI (CLP).

$\square$ Nei, av de kontrollerte stoffblandingene har inn holdsstoffer med feil klassifisering i henhold til tabell 3.1 i Annex VI (CLP).

3.2.2. Er de kontrollerte stoffblandingene klassifisert riktig i SDS pkt. 2.1 ut i fra konsentrasjonsintervaller og fareklassifisering av innholdsstoffer angitt i SDS punkt 3.2?

$\mathrm{Ja}$

Nei, av de kontrollerte stoffblandingene har feil klassifisering ut i fra opplysninger om innholdsstoffer.

$\square$ Uavklart om klassifiseringen er riktig for av de__ kontrollerte stoffblandingene ( fordi det kreves bedre dokumentasjon/ opplysninger for å kunne angi korrekt klassifisering). 


\subsection{Kontroll av sikkerhetsdatablad (SDS)}

Merknad til inspektør: i dette prosjektet er det kun obligatorisk å kontrollere opplysninger i rubrikkene ("Sections") 2 (fareidentifikasjon), 3 (sammensetning/angivelse av bestanddeler) og 12 (økologiske opplysninger), i tillegg til at de obligatoriske rubrikker/underrubrikker angitt i 453/2010 del B er oppgitt.

4.1. Har virksomheten utarbeidet sikkerhetsdatablad (SDS) for de kontrollerte stoffene i henhold til kravene i REACH vedlegg II, 453/2010 vedlegg "I"?
$\mathrm{Ja}$
Nei, __ av de
«gamle» formatet.
kontrollerte SDS er utarbeidet etter det
$\square$ Ja, men av de kontrollerte SDS inneholder feil/ mangler i henhold til REACH 453/2010 "I"?

Angi antall SDS med feil/mangler nedenfor:

SDS mangler obligatoriske underrubrikker i henhold til Del B til $453 / 2010$

SDS mangler dobbel klassifisering under avsnitt 2.1

SDS har dobbel merking under avsnitt 2.2

SDS har feil under avsnitt 12 (informasjon mangler eller sams varer ikke med klassifiseringen)

SDS har andre feil/mangler i avsnitt 2, 3 og 12.

4.2. Har virksomheten utarbeidet sikkerhetsdatablad (SDS) for stoffblandingene i henhold til kravene i REACH 453/2010 artikkel 2.3 - 6 og vedlegg "II"?

$\square \mathrm{Ja}$ av de kontrollerte SDS er i henhold til det «gamla» formatet.

$\square$ Ja, men, av de kontrollerte SDS inneholder feil/ mang ler i henhold til REACH 53/2010 "II". 
Ange antall noterte feil/mangler nedenfor:

SDS mangler obligatoriske underrubrikker i henhold til Del B til $453 / 2010$

SDS mangler dobbel klassifisering under avsnitt 2.1

SDS har dobbel merking under avsnitt 2.2

SDS mangler dobbel klassifisering for innholdsstoffer under avsnitt 3.2

SDS har feil under avsnitt 12 (informasjon mangler eller sams varer ikke med klassifiseringen)

SDS har andre feil/mangler i avsnitt 2, 3 og 12.

4.3 Angis M-faktorer under avsnitt 2 og/eller 3 i SDS for de stoffene som er klassifisert med "Aquatic Acute 1" eller "Aquatic Chronic 1"? (NB! Dette er ikke et krav, men er sterkt anbefalt fordi M-faktor er en viktig del i klassifiseringen av en stoffblanding)

$\square$ Ja

$\square$ Nei

Ikke relevant

\subsection{Kontroll av etikett/merking}

\subsection{Etikettopplysninger}

Inneholder etikettene for de kontrollerte stoffene/stoffblandingene de obligatoriske opplysningene i henhold til artikkel 17 og 25?

$\square \mathrm{Ja}$

$\square \mathrm{Nei}, \ldots$ av de ___ kontrollerte etikettene manglet obligatoriske opplysninger eller har feilaktige opplysninger.

Angi antallet av etiketter med feil/mangler nedenfor:

Kontaktopplysninger

Produktidentifikatorer 
Farepiktogram

_ Signalord

__Fareangivelser

__ Sikkerhetsangivelser

__Ytterligere merkeopplysninger (eks. EUH-setninger)

__ Språket

_ Tydlig og lettlest (art 31)

__Flerspråksetikett/multi-layered etikett

_Annet

5.2 Samsvar mellom etikett og avsnitt 2, punkt 2.2 i SDS (REACH 453/2010, vedlegg "I" og "II").

5.2.1. Samsvarer merkeopplysninger for de kontrollerte stoffene med avsnitt 2, punkt 2.2 i tilhørende SDS?

$\mathrm{Ja}$

$\square$ Nei, av de kontrollerte stoffene har forskjellig merkeopplysninger i etikett og tilhørende SDS.

5.2.2. Samsvarer merkeopplysninger for de kontrollerte stoffblandingene angitt i avsnitt 2, punkt 2.2 i tilhørende SDS?

$\mathrm{Ja}$

Nei, av de kontrollerte stoffblandingene har forskjel lig merkeopplysninger i etikett og tilhørende SDS. 


\subsection{Kontroll av barnesikret lukning og følbar advar- selsmerking (art.35) dersom noen av de kontrollerte stoffene/stoffblandingene leveres til allmenheten}

6.1. Har de kontrollerte stoff/stoffblanding påkrevd barnesikret lukning (CLP art. 35 vedlegg II, avsnitt 3.1.1, 3.1.2, 3.1.3 og 3.1.4.2)?

$\square \mathrm{Ja}$

$\square$ Nei___av de___ kontrollerte stoff(ene)/stoffblanding(ene) mangler barnesikret lukning.

$\square$ Ikke relevant

6.2. Har de kontrollerte stoff(ene)/stoffblanding(ene) følbar (taktil) advarselsmerking (CLP art. 35 vedlegg II, avsnitt 3.2.1 og 3.2.2)?

$\square$ Ja

$\square$ Nei___av de___ kontrollerte stoff(ene)/stoffblanding(ene)

mangler følbar (taktil) advarselsmerking.

$\square$ Ikke relevant

\subsection{Kontroll av Netthandel (art 48)}

7.1 Oppfyller virksomheten kravet til informasjon i henhold til art. 48 ved reklame/netthandel?

$\square$ Ja
$\square$ Nei
$\square$ Ikke relevant 
Tilsynsmyndighetene for kjemikalier i Danmark, Sverige, Finland og Norge har gjennomført et felles tilsynsprosjekt i 2012-2013.

Hovedformålet med prosjektet har vært å kontrollere om nordiske importører, produsenter og distributører av kjemikalier etterlever det nye klassifiserings- og merkingsregelverket CLP (Classification, Labelling and Packaging) som trådte i kraft i 2010. Prosjektet omfattet også kontroll av klassifisering og merking i sikkerhetsdatabladene og at sikkerhetsdatabladene følger de nye kravene i vedlegg II til REACH (forordning (EU) nr. 453/2010). Det ble også kontrollert om virksomhetene hadde overholdt meldeplikten for kjemiske stoffer til det europeiske kjemikaliebyrået (ECHA). Rapporten gir en oversikt over gjennomføringen av prosjektet og lovgivningen for kjemikalier i EU/ EØS området. Resultater og konklusjoner er beskrevet bå de for hver enkelt land og samlet.

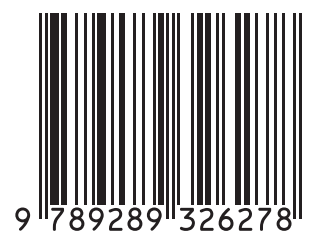

